\title{
Neto2 Modulation of Kainate Receptors with Different Subunit Compositions
}

\author{
Christoph Straub, ${ }^{1}$ Wei Zhang, ${ }^{2}$ and James R. Howe ${ }^{2}$ \\ ${ }^{1}$ Department of Cellular and Molecular Physiology and Program in Cellular Neuroscience, Neurodegeneration and Repair, and ${ }^{2}$ Department of \\ Pharmacology, Yale University School of Medicine, New Haven, Connecticut 06520
}

\begin{abstract}
Kainate receptors are less well understood than other glutamate receptors, and synaptic kainate receptors display properties that differ from recombinant receptors. In particular, the slow decay of kainate receptor synaptic currents contrasts with the rapid deactivation and desensitization of receptors expressed in heterologous cells. We recently identified Neuropilin and Tolloid like-2 (Neto2) as a novel accessory subunit of kainate receptors and showed that Neto2 modulates the gating kinetics of GluK2 receptors. However, the kainate receptor family consists of five different subunits (GluK1-5) that can form homomeric and heteromeric receptors with different functional properties. Here, we tested whether Neto 2 modulation varies with subunit composition. Rapid application techniques were used to apply glutamate to outside- out patches that contained GluK1, GluK1/5, or GluK2/5 kainate receptors. Coexpression of Neto2 slowed desensitization to varying degrees. Responses to 1 ms pulses of glutamate were also slowed by Neto2, especially for receptors containing GluK5, as were postsynaptic currents in neurons expressing recombinant kainate receptors. In addition, Neto2 markedly increased the rate at which some receptors recovered from desensitization. These results suggest that Neto2 modulates the function of most kainate receptors.
\end{abstract}

\section{Introduction}

Glutamate is the main excitatory neurotransmitter in the brain, where it acts on three classes of ionotropic glutamate receptors: AMPA, NMDA, and kainate receptors (KARs) (Hollmann and Heinemann, 1994; Dingledine et al., 1999). Despite significant sequence homology and a shared architecture, the receptor subfamilies behave differently in response to glutamate and fulfill different roles in synaptic transmission. The role of KARs in synaptic transmission is less well understood than those of AMPA and NMDA receptors, and the receptors display several puzzling features (Huettner, 2003; Lerma, 2003). Notably, whereas synaptic KAR currents decay in tens or hundreds of milliseconds and are much slower than synaptic currents through AMPA receptors (Castillo et al., 1997; Vignes and Collingridge, 1997; Kidd and Isaac, 1999; Cossart et al., 2002), heterologously expressed KARs deactivate and desensitize rapidly with time constants similar to AMPA receptors (Dingledine et al., 1999; Erreger et al., 2004). The reasons for this discrepancy remain unclear, although GluK5-containing receptors display slow deactivation at nonsaturating concentrations of glutamate (Barberis et al., 2008).

The family of KARs consists of five subunits, the low-affinity subunits GluK1-3 and the high affinity subunits GluK4/5. GluK1-3 are capable of forming functional homomeric ion chan-

\footnotetext{
Received Jan. 3, 2011; revised March 16, 2011; accepted April 6, 2011

Author contributions: J.R.H. designed research; C.S. and W.Z. performed research; C.S., W.Z., and J.R.H. analyzed data; C.S. and J.R.H. wrote the paper.

This work was supported by National Institutes of Health Grant NS057725 (J.R.H.). C.S. is supported by a Boehringer Ingelheim Foundation PhD fellowship. We thank Mark Mayer for the GluK1 construct and thank Susumu Tomita for providing cerebellar granule cells from stargazer mice and for insightful comments on this manuscript.

Correspondence should be addressed to James R. Howe, Department of Pharmacology, Yale School of Medicine, 333 Cedar Street, P0 Box 208066, New Haven, CT 06520-8066, E-mail: james.howe@yale.edu.

DOI:10.1523/JNEUROSCI.0024-11.2011

Copyright $\odot 2011$ the authors $\quad 0270-6474 / 11 / 318078-05 \$ 15.00 / 0$
}

nels, while GluK4/5 have to coassemble with GluK1, 2, or 3, and endogenous KARs are believed to be mostly heteromers (Christensen et al., 2004; Ruiz et al., 2005; Nasu-Nishimura et al., 2006; Fernandes et al., 2009). We recently identified Neuropilin and Tolloid like-2 (Neto2) as a novel accessory subunit of KARs (Zhang et al., 2009). Neto2 interacts specifically with recombinant and native GluK1 and GluK2 and modulates KAR currents in vitro and in vivo. In our initial analysis, we demonstrated that Neto 2 increases the open probability and burst length of individual GluK2 receptors and also speeds recovery from desensitization.

Since different KAR subunits and combinations form receptors with distinct properties and roles in synaptic transmission (Huettner, 2003; Lerma, 2003; Christensen et al., 2004; Erreger et al., 2004; Pinheiro and Mulle, 2006), we test here whether Neto2 also modulates the behavior of receptors formed from other KAR subunits. We focused on GluK1 and GluK2, both with and without GluK5. These three subunits are best studied, show the broadest expression in brain, and are generally thought to account for most of KAR-mediated synaptic transmission (Hollmann and Heinemann, 1994; Lerma, 2003; Pinheiro and Mulle, 2006). We found that Neto 2 modulates all combinations of KARs tested, but the effects varied quantitatively with subunit composition. In total, our results imply that Neto2 is a ubiquitous modulator of KARs and suggest a role for Neto2 in shaping endogenous KAR-mediated synaptic currents.

\section{Materials and Methods}

Cell culture and transfection. tsA201 cells were plated onto $12 \mathrm{~mm}$ glass coverslips coated with $100 \mu \mathrm{g} / \mathrm{ml}$ poly-L-lysine, and the cells were maintained in humidified $95 \% \mathrm{H}_{2} \mathrm{O} / 5 \% \quad \mathrm{CO}_{2}$. Transfections were made with Lipofectamine 2000 (Invitrogen) according to the manufacture's protocol. 
GluK5 and/or Neto2 were transfected in fourfold excess relative to GluK1/2. To identify transfected cells, eGFP was cotransfected at a ratio of 1:10.

Cerebellar granule cell cultures and transfections were performed as described previously (Zhang et al., 2009). In short, primary cultures from stargazer mice were made at postnatal day 7, transfected at DIV 5 using the calcium-phosphate method, and recorded from at DIV 7-10. Stargazer mice were obtained from the Jackson Laboratory and were maintained at the Yale animal facility under the guidelines of the Institutional Animal Care and Use Committee.

Electrophysiology. Recordings from outside-out patches were performed $2-3 \mathrm{~d}$ after transfection at room temperature as described previously (Robert et al., 2001). The holding potential was $-70 \mathrm{mV}$ or -100 $\mathrm{mV}$, and series resistance compensation was set at $60-80 \%$. The external solution was as follows (in mM): $150 \mathrm{NaCl}, 3 \mathrm{KCl}, 2 \mathrm{CaCl}_{2}, 1 \mathrm{MgCl}_{2}, 2.5$ glucose, and 10 HEPES, pH 7.4. Patch pipettes (open-tip resistance, 3-5 MOhm) were filled with a solution containing (in mM) $120 \mathrm{KF}, 33 \mathrm{KOH}$, $2 \mathrm{MgCl}_{2}, 1 \mathrm{CaCl}_{2}, 11$ EGTA, and 10 HEPES, pH 7.4. Glutamate was added to the external solution and was applied with theta glass pipettes mounted on a piezoelectric bimorph. The $10-90 \%$ rise times of agonistevoked currents were $0.3-0.6 \mathrm{~ms}$, and the rate of solution exchange estimated from open-tip potentials was $100-200 \mu$ s. The bath was superfused constantly with normal external solution at a rate of $1 \mathrm{ml} / \mathrm{min}$. Agonist-evoked currents recorded in outside-out patches were analog low-pass filtered at $3 \mathrm{kHz}$ and sampled at rates of $20-50 \mathrm{kHz}$.

Synaptic currents were recorded in whole-cell mode at room temperature and a holding potential of $-70 \mathrm{mV}$. The external solution contained the following (in mM): $140 \mathrm{NaCl}, 2.5 \mathrm{KCl}, 2.5 \mathrm{CaCl}_{2}, 1.3 \mathrm{MgSO}_{4}$, $2.7 \mathrm{MgCl}_{2}, 10$ glucose, and 10 HEPES. The pipette solution contained the following (in mM): 130 Cs-methanesulfonate, 5 HEPES, 5 Mg-ATP, 0.2 Na-GTP, 20 TEA, 5 and EGTA.

Data analysis and statistics. Digitized records were transferred to IGOR software (Wavemetrics) and analyzed as described previously (Robert et al., 2001). In many cases, the decays of ensemble currents were biexponential. The time constants and relative amplitudes obtained from biexponential fits to these decays were used to calculate weighted tau values. Synaptic currents were aligned at the $50 \%$ rise-time and averaged. The frequency of events was low ( $<5$ events per minute), and all events from an individual cell were used for analysis. Results are given as mean \pm SEM. Mean values with and without Neto2 were compared with Student's $t$ test, and $p<0.05$ was considered statistically significant.

\section{Results}

The effect of Neto2 on desensitization of kainate receptors

We recently identified Neto 2 as a novel accessory subunit of KARs and reported it modulated the kinetics of homomeric GluK2 receptors (Zhang et al., 2009). To determine whether Neto 2 also modulates the kinetics of receptors formed from other widely expressed KAR subunits, we coexpressed Neto2 with GluK1, as well as GluK1 or GluK2 with GluK5.

We first analyzed desensitization kinetics. Coexpression of Neto2 slowed desensitization of GluK1 receptors sevenfold (weighted tau, $1.6 \pm 0.2 \mathrm{~ms}$ and $11.2 \pm 1.7 \mathrm{~ms}$, respectively) (Fig. $1 a$ ), similar to what we observed before for GluK2 (Zhang et al., 2009). Whereas GluK1 desensitization was frequently fitted well by a single exponential in the absence of Neto2 ( 4 of 8 patches), in the presence of Neto 2 desensitization was clearly biexponential ( 9 of 9 patches) (Fig. 1 $a, f$ ). The second, slow component of decay was slower and more pronounced with Neto2 (Fig. 1e,f). In addition, coexpression of Neto 2 resulted in a substantial increase in the steady-state current (Fig. 1a,g).

Receptors composed of GluK1 and GluK5 desensitized monoexponentially and more rapidly than GluK1 homomers (weighted tau, $0.7 \pm 0.1 \mathrm{~ms}$ and $1.6 \pm 0.2 \mathrm{~ms}$, respectively) (Fig. $1 a, b)$. Coexpression of Neto2 slowed desensitization of GluK1/5 heteromers several fold (weighted tau, $3.3 \pm 0.5 \mathrm{~ms}$ for GluK1/5 + Neto2) (Fig. 1b). This effect was partially at-
2

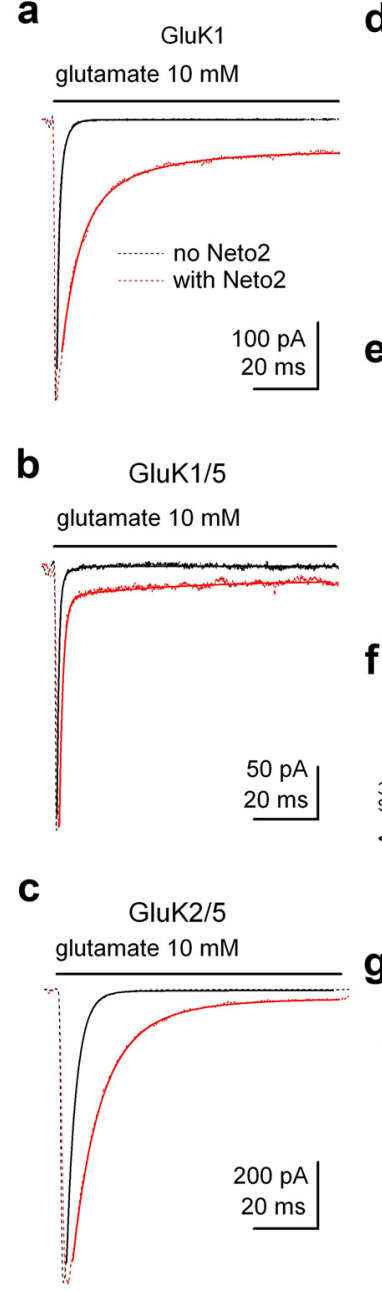

d

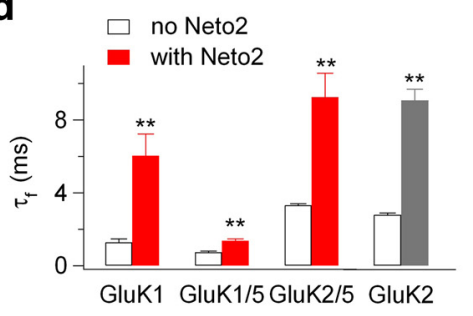

e

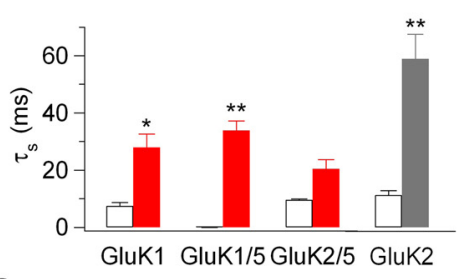

f

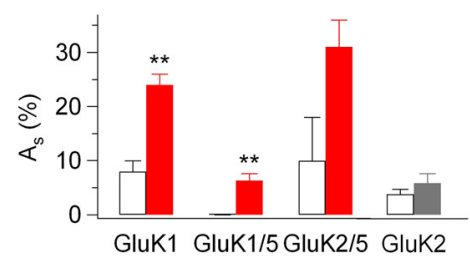

g

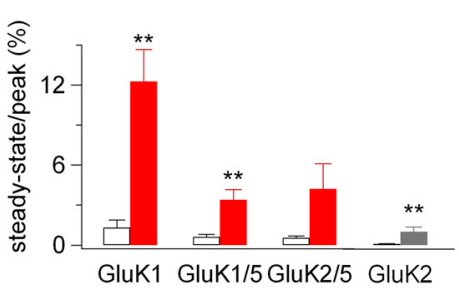

Figure 1. Net02 modulates desensitization of different KAR subunits. $\boldsymbol{a}-\boldsymbol{c}$, Currents evoked in outside- out patches from cells that were transfected with the indicated KAR subunits either without (black) or with (red) Net02. Glutamate (10 mm) was applied for $100 \mathrm{~ms}$ (bars above traces). The monoexponential or biexponential fits to the decays of the currents (solid lines) are superposed on the data (dotted lines). The amplitude calibrations refer to the results without Net02. The currents with Net02 coexpression were scaled so that the peak currents were the same for each pair of results. $\boldsymbol{d}-\boldsymbol{g}$, Bar graphs showing the mean results obtained for each subunit combination tested without (open bars) or with (red bars) Net02 for the parameters obtained from fits to the desensitization decays: $\boldsymbol{d}$, time constant of the fast component of desensitization; $\boldsymbol{e}, \boldsymbol{f}$, time constant and relative amplitude of the slow component of desensitization (mean values from only those patches where a slow component was observed); $\boldsymbol{g}$, steady-state current as a percentage of the peak. The results we obtained before with GluK2 are also shown (gray) (Zhang et al., 2009). Error bars indicate SEM. * $p<0.05$, ${ }^{* *} p<0.01 ; n=6-9$ for each group tested.

tributable a slower fast component of decay but mostly to the appearance of a second, very slow component that was not seen without Neto 2 (Fig. $1 b, e, f$ ). In addition, Neto 2 coexpression increased the steady-state current, which was nearly undetectable without Neto2 (Fig. $1 g$ ).

Heteromeric GluK2/5 receptors desensitized with kinetics similar to GluK2 homomers (Fig. 1c) (Zhang et al., 2009) and followed single-exponential kinetics. As for the other subunit combinations, Neto2 slowed the desensitization of GluK2/5 receptors (Fig. 1c) (weighted tau, $3.5 \pm 0.2$ vs $11.4 \pm 1.2 \mathrm{~ms}$ ). However, in contrast to results with GluK2 and Neto2, and the findings here with Neto2 and GluK1-containing receptors, some currents decayed monoexponentially ( 4 of 8 patches), and the slow component of desensitization was, when observed, not significantly accentuated by Neto 2 coexpression (Fig. 1e,f). Steady-state currents for GluK2/5 receptors were 
increased in the presence of Neto2, although the increase was not statistically significant (Fig. 1c,g).

\section{Neto2 accelerates recovery from desensitization}

The appearance of a large slow component in the desensitization decays of GluK2 currents was because of an effect of Neto2 to cause some GluK2 homomeric receptors to recover faster from desensitization (Zhang et al., 2009). Since coexpression of Neto2 also caused the appearance of a slow component in the desensitization decays of currents through GluK1, GluK1/5, and GluK2/5 receptors, and increased steadystate currents, we tested whether Neto2 also altered recovery from desensitization for these receptors.

Results obtained from two-pulse protocols to measure recovery from desensitization for GluK1, GluK1/5, and GluK2/5 receptors are shown in Figure 2. In the absence of Neto2, recovery followed a sigmoid time course (Bowie and Lange, 2002) and was slow for all three receptor types. Hodgkin-Huxley fits (Robert and Howe, 2003) to the mean results gave time constants for GluK1, GluK1/5, and GluK2/5 receptors of 2.9, 3.8, and $2.5 \mathrm{~s}$, respectively. Coexpression of Neto2 dramatically increased recovery at short interpulse intervals, and recovery was evident for all receptor types at times when there was virtually no recovery without Neto2 (Fig. 2a-c). Hodgkin-Huxley fits to the data showed that Neto2 caused the appearance of a fast component of recovery (Fig. $2 d-f$ ), which had time constants of 50, 450, and 61 $\mathrm{ms}$ for GluK1, GluK1/5, and GluK2/5 receptors, respectively. For all three receptor types, the time course of the slow component of recovery was similar to that seen without Neto2 (Fig. $2 d-f$ ). The time constants of the slow component with Neto2 agreed within $5 \%$ with the corresponding values obtained without Neto2, results similar to findings for GluK2 homomeric receptors (Zhang et al., 2009).

\section{The effect of Neto2 on KAR responses to brief pulses of glutamate}

To test the effects of Neto 2 on receptor responses to stimuli similar to those they are exposed to during synaptic transmission, we studied the effect of Neto2 on the response of the receptors to 1 ms pulses of $10 \mathrm{~mm}$ glutamate (we refer to the decay of these responses as deactivation).

Both with and without Neto2, deactivation decays for GluK1 receptors were in most cases adequately fitted by single exponential functions (Fig. 3a) (4 of 5 patches for GluK1 and 5 of 6 patches for GluK1 + Neto2). Coexpression of Neto2 slowed deactivation for GluK1 receptors (Fig. 3a,d), and weighted deactivation time constants were approximately doubled (weighted tau, $1.7 \pm 0.4 \mathrm{~ms}$ vs $3.9 \pm 0.7 \mathrm{~ms})$. The deactivation of GluK1/5 receptors was fast and monoexponential in the absence of Neto2 (Fig. $3 b, d, f$ ). In the presence of Neto2, deactivation became clearly biexponential (Fig. 3b). The fast component of deactivation in the presence of Neto2 had a time constant close to the monoexponential decay in its absence (Fig. 3d); however, the second, additional component b

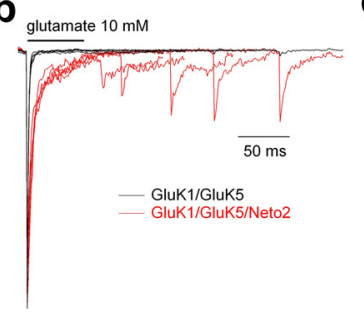

C
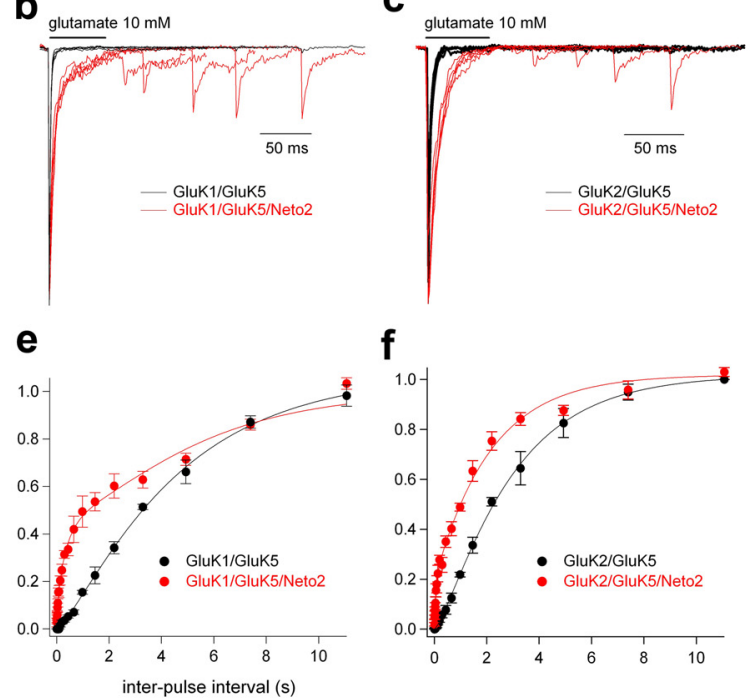

f

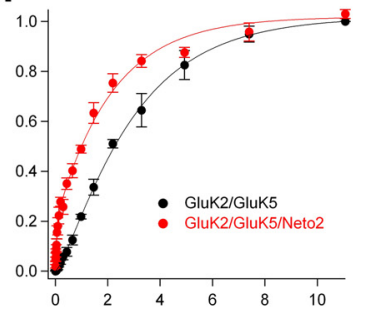

Figure 2. Net02 accelerates recovery from desensitization. $\boldsymbol{a}-\boldsymbol{c}$, Results from two-pulse experiments illustrating the early Net02. An initial $100 \mathrm{~ms}$ application of $10 \mathrm{~mm}$ glutamate was made and then repeated at various interpulse intervals. The envelop calibrations refer to the results without Net02. The currents with Net02 coexpression were scaled so that the peak currents were the

decayed much more slowly and accounted for $8.8 \pm 1 \%$ of the overall amplitude (Fig. 2e,f).

Deactivation for GluK2/5 receptors was slightly slower than deactivation for GluK2 alone, and coexpression of Neto2 slowed deactivation of GluK2/5 receptors to a greater degree than for GluK2 homomers (approximately threefold) (Fig. 3c,d). However, the relative slowing of deactivation kinetics for GluK2/5 receptors was less profound than for GluK1/5 receptors, and a distinguishable slow component was observed only in one case.

\section{Neto2 slows postsynaptic GluK1 currents}

We next sought to determine whether, as for GluK2 (Zhang et al., 2009), Neto2 would modulate GluK1-containing receptors in a synaptic environment. Cerebellar granule cells express GluK1, GluK2, and GluK5 (Belcher and Howe, 1997; Ripellino et al., 1998). Whole-cell and unitary kainate receptor currents, but not EPSCs, can be recorded from these cells after reducing desensitization with concanavalin A (Pemberton et al., 1998; Smith et al., 1999), although the currents are small and difficult to isolate pharmacologically. Cerebellar granule cells from stargazer (stargazin-deficient) mice form functional glutamatergic synapses in culture but do not display AMPA receptor-mediated EPSCs (Hashimoto et al., 1999; Chen et al., 2000). We, therefore, used this system to examine the effect of Neto2 on synaptic KARs by over-expressing GluK1 in transfected neurons. NMDA and GABA receptors were blocked with AP-5 (100 $\mu \mathrm{M})$ and picrotoxin $(50 \mu \mathrm{M})$, respectively.

Cerebellar granule cells from stargazer mice that were transfected with GluK1 displayed small EPSCs (Fig. 4a) that were not observed after transfection with GFP alone. The EPSCs in GluK1transfected neurons decayed twice as fast as AMPA receptormediated EPSCs in wild-type granule cells, or EPSCs in stargazer granule cells in which AMPA receptor transmission was rescued (Cho et al., 2007), and had time constants similar to those ob- 

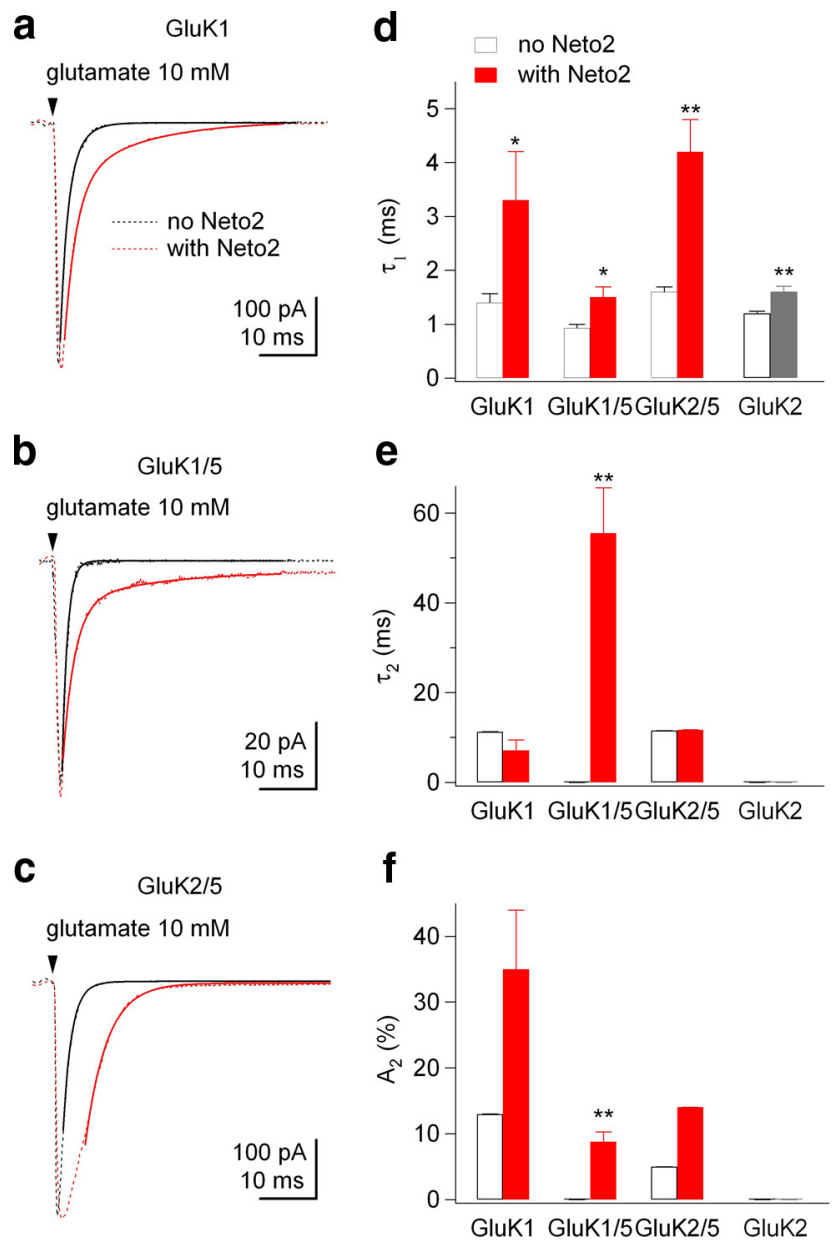

Figure 3. Net02 modulates responses to brief pulses of glutamate. $\boldsymbol{a}-\boldsymbol{c}$, Currents evoked in outside- out patches from cells that were transfected with the indicated KAR subunits either without (black) or with (red) Neto2. Glutamate ( $10 \mathrm{~mm}$ ) was applied for $1 \mathrm{~ms}$ (arrowhead). The monoexponential or biexponential fits to the decays of the currents (solid lines) are superposed on the data (dotted lines). The amplitude calibrations refer to the results without Net02. The currents with Net02 coexpression were scaled so that the peak currents were the same for each pair of results. $\boldsymbol{d}-\boldsymbol{f}$, Bar graphs showing the mean results obtained for each subunit combination tested without (open bars) or with (red bars) Net02 for the parameters obtained from fits to the deactivation decays: $\boldsymbol{d}$, time constant of the fast component of deactivation; $\boldsymbol{e}, \boldsymbol{f}$, time constant and relative amplitude of the slow component of deactivation (mean values from only those patches where a slow component was observed). The results we obtained before with GluK2 are also shown (gray) (Zhang et al., 2009). Error bars indicate SEM. For GluK2/5 receptors, and GluK1 without Net02, a slow component was only observed in one patch. ${ }^{*} p<0.05,{ }^{* *} p<0.01 ; n=5-7$ for each group tested.

served for GluK1/5 heteromeric receptors in deactivation protocols (compare Figs. $4 c, e$ and $3 b, d$ ). Cotransfection of GluK1 and Neto2 resulted in a significant, nearly threefold, slowing of synaptic currents (Fig. $4 d, e$ ), confirming that Neto 2 modulation of KAR gating remains intact for GluK1-containing receptors that are localized to synapses.

\section{Discussion}

The results reported here extend our previous work on modulation of GluK2 gating by Neto2 (Zhang et al., 2009) and show that Neto 2 also modulates the gating of GluK1 receptors, as well as receptors containing GluK5 in combination with GluK1 and GluK2. While Neto2 modulation varies quantitatively with subunit composition, the effects of Neto 2 are qualitatively similar for all receptors studied, and our results suggest that the coexpression of Neto 2 likely modulates the gating behavior of most native kainate receptors in brain.

\section{Neto2 modulation of desensitization}

As was the case for GluK2 receptors, the primary effect of Neto2 on the KARs studied here appears to be on conformational changes associated with entry into and recovery from desensitization. Although Neto2 significantly slowed the decay of currents through GluK1 receptors evoked by a $1 \mathrm{~ms}$ pulse of glutamate, the similar deactivation and desensitization time constants for GluK1 receptors in the absence of Neto2 suggest that desensitization contributes substantially to the decay of GluK1 receptor currents, even when very brief pulses of glutamate are applied. The effects of Neto 2 on deactivation kinetics were larger for receptors that contained GluK5 subunits. However, the deactivation and desensitization time constants were also similar for these receptors, both with and without Neto2. Presumably, inclusion of the high-affinity GluK5 subunit in receptor assemblies slows the rate at which glutamate dissociates (Barberis et al., 2008), and receptor gating is terminated not by glutamate unbinding but by desensitization, at least at saturating concentrations of glutamate.

The coexpression of Neto2 had a large effect on the early phase of recovery from desensitization for all receptors tested and resulted in the appearance of a fast component of recovery, as we found before for GluK2 receptors (Zhang et al., 2009). In our work on GluK2, we were able to transfect Neto2 at large excess and demonstrate that a 10:1 cDNA ratio (Neto2:GluK2) produced maximal effects on GluK2 gating, suggesting that the receptors with unaltered recovery kinetics were unlikely to represent receptors not associated with Neto2. Because GluK1 and GluK5 did not express as well as GluK2, we were unable to express Neto2 at greater than a 4:1 excess. It is, therefore, possible that the patches studied here contained a mixed population of receptors and that the receptors with unaltered recovery kinetics were receptors with incomplete inclusion of Neto2. Alternatively, Neto2 may promote gating behavior with distinct recovery kinetics, and individual receptors associated with Neto2 may switch between this behavior and the gating behavior seen in the absence of Neto2.

For GluK2, Neto2 also increased the amplitude of peak currents (Zhang et al., 2009). Whether this is true for the receptors studied here is unclear. Although we expect this is the case, confirmation of this expectation would require single-channel recordings in patches containing only a few receptors.

\section{Neto2 modulation and subunit composition}

Coexpression of GluK5 with and without Neto2 had different effects on the properties of receptors containing GluK1 and GluK2. GluK1/5 heteromeric receptors showed extremely rapid desensitization and deactivation, consistent with initial reports on GluK5 (Herb et al., 1992). The slower kinetics of GluK1/5 receptors when coexpressed with Neto 2 was mostly attributable to the appearance of an additional slow component of decay that accounted for $\sim 10 \%$ of the overall amplitude. In contrast, GluK5 only slightly slowed desensitization and deactivation for GluK2 receptors, although the effect of Neto2 on deactivation was greater for GluK2/5 heteromers. This finding is consistent with in vivo data for GluK2-dependent EPSCs at mossy fiber-CA3 synapses in the hippocampus (Mulle et al., 1998), which decay faster in GluK5-deficient mice (Contractor et al., 2003).

\section{NETO2 modulates KAR-mediated synaptic currents}

Synaptic transmission is generally thought to reflect a situation similar to a deactivation protocol (Clements et al., 1992). Interestingly, Neto 2 enhanced the slow component of decay in deactivation protocols, especially for GluK1/GluK5 receptors, indicating that glutamate stays bound long after the removal of 
glutamate. We, therefore, tested the effect of Neto2 on synaptic GluK1 currents directly, using cerebellar granule cells from stargazer mice. Overexpression of GluK1 resulted in small low-frequency EPSCs that decayed extremely rapidly, suggesting an association with endogenous GluK5. While coexpression of Neto2 slowed the decay of these EPSCs approximately threefold, we did not observe a second, very slow, component as we did in a deactivation protocol. However, it should be noted that the currents we recorded were very small (10-25 pA), and a slow component that was only $10 \%$ or so of the peak amplitude could easily be missed. It is also important to emphasize that the system used here is artificial, and other endogenous binding partners or morphological features that are not present in culture might influence physiological synaptic currents.

\section{References}

Barberis A, Sachidhanandam S, Mulle C (2008) GluR6/KA2 kainate receptors mediate slow-deactivating currents. J Neurosci 28: 6402-6406.

Belcher SM, Howe JR (1997) Characterization of RNA editing of the glutamate-receptor subunits GluR5 and GluR6 in granule cells during cerebellar development. Brain Res Mol Brain Res 52:130-138.

Bowie D, Lange GD (2002) Functional stoichiometry of glutamate receptor desensitization. J Neurosci 22:3392-3403.

Castillo PE, Malenka RC, Nicoll RA (1997) Kainate receptors mediate a slow postsynaptic current in hippocampal CA3 neurons. Nature 388:182-186.

Chen L, Chetkovich DM, Petralia RS, Sweeney NT, Kawasaki Y, Wenthold RJ, Bredt DS, Nicoll RA (2000) Stargazin regulates synaptic targeting of AMPA receptors by two distinct mechanisms. Nature 408:936-943.

Cho CH, St-Gelais F, Zhang W, Tomita S, Howe JR (2007) Two families of TARP isoforms that have distinct effects on the kinetic properties of AMPA receptors and synaptic currents. Neuron 55:890-904.

Christensen JK, Paternain AV, Selak S, Ahring PK, Lerma J (2004) A mosaic of functional kainate receptors in hippocampal interneurons. J Neurosci 24:8986-8993.

Clements JD, Lester RA, Tong G, Jahr CE, Westbrook GL (1992) The time course of glutamate in the synaptic cleft. Science 258:1498-1501.

Contractor A, Sailer AW, Darstein M, Maron C, Xu J, Swanson GT, Heinemann SF (2003) Loss of kainate receptor-mediated heterosynaptic facilitation of mossy-fiber synapses in KA2 ${ }^{-1-}$ mice. J Neurosci 23:422-429.

Cossart R, Epsztein J, Tyzio R, Becq H, Hirsch J, Ben-Ari Y, Crépel V (2002) Quantal release of glutamate generates pure kainate and mixed AMPA/ kainate EPSCs in hippocampal neurons. Neuron 35:147-159.

Dingledine R, Borges K, Bowie D, Traynelis SF (1999) The glutamate receptor ion channels. Pharmacol Rev 51:7-61.

Erreger K, Chen PE, Wyllie DJ, Traynelis SF (2004) Glutamate receptor gating. Crit Rev Neurobiol 16:187-224.

Fernandes HB, Catches JS, Petralia RS, Copits BA, Xu J, Russell TA, Swanson GT, Contractor A (2009) High-affinity kainate receptor subunits are necessary for ionotropic but not metabotropic signaling. Neuron 63:818-829.

Hashimoto K, Fukaya M, Qiao X, Sakimura K, Watanabe M, Kano M (1999) Impairment of AMPA receptor function in cerebellar granule cells of ataxic mutant mouse stargazer. J Neurosci 19:6027-6036.

Herb A, Burnashev N, Werner P, Sakmann B, Wisden W, Seeburg PH (1992) The KA-2 subunit of excitatory amino acid receptors shows widespread expression in brain and forms ion channels with distantly related subunits. Neuron 8:775-785.

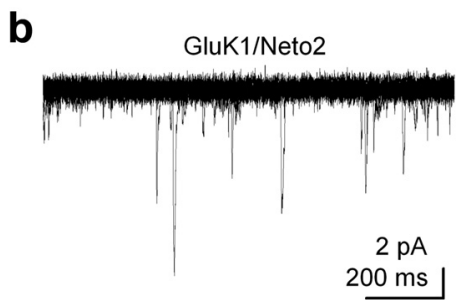

GluK1

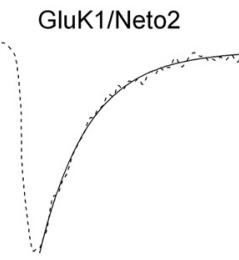

$5 \mathrm{~ms}$

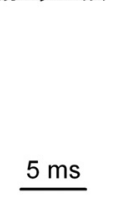

e $\square$ GluK1

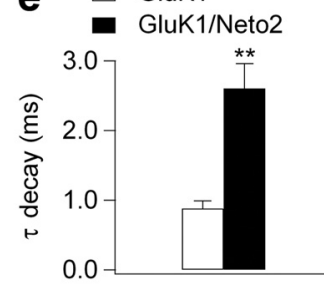

0.0
$2 \mathrm{pA}$

$00 \mathrm{~ms}$

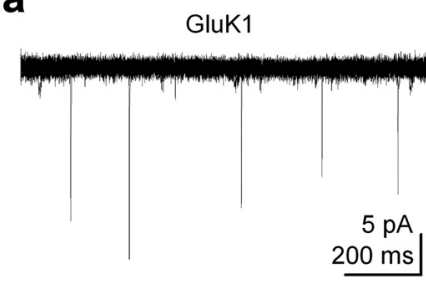

uK1 naptic GluK1 currents. Primary cultures of cerebellar granule cells from stargazer mice were
MK1 and Net02. Expression of eGFP was used to identify transfected neurons. Neurons transfected synaptic activity, but spontaneous synaptic currents were consistently observed in neurons transNeto2 $(\boldsymbol{b})$. The examples shown in $\boldsymbol{a}$ and $\boldsymbol{b}$ are five superposed segments of data and do not es obtained from cells transfected with GluK1 (c) or GluK1 and Net02 (d).e, Bar graph showing mean SEM. ${ }^{* *} p<0.01 ; n=4$ and 5 .

Hollmann M, Heinemann S (1994) Cloned glutamate receptors. Annu Rev Neurosci 17:31-108.

Huettner JE (2003) Kainate receptors and synaptic transmission. Prog Neurobiol 70:387-407.

Kidd FL, Isaac JT (1999) Developmental and activity-dependent regulation of kainate receptors at thalamocortical synapses. Nature 400:569-573.

Lerma J (2003) Roles and rules of kainate receptors in synaptic transmission. Nat Rev Neurosci 4:481-495.

Mulle C, Sailer A, Pérez-Otaño I, Dickinson-Anson H, Castillo PE, Bureau I, Maron C, Gage FH, Mann JR, Bettler B, Heinemann SF (1998) Altered synaptic physiology and reduced susceptibility to kainate-induced seizures in GluR6-deficient mice. Nature 392:601-605.

Nasu-Nishimura Y, Hurtado D, Braud S, Tang TT, Isaac JT, Roche KW (2006) Identification of an endoplasmic reticulum-retention motif in an intracellular loop of the kainate receptor subunit KA2. J Neurosci 26:7014-7021.

Pemberton KE, Belcher SM, Ripellino JA, Howe JR (1998) High-affinity kainate-type ion channels in rat cerebellar granule cells. J Physiol 510:401-420

Pinheiro P, Mulle C (2006) Kainate receptors. Cell Tissue Res 326:457-482.

Ripellino JA, Neve RL, Howe JR (1998) Expression and heteromeric interactions of non-N-methyl-D-aspartate glutamate receptor subunits in the developing and adult cerebellum. Neuroscience 82:485-497.

Robert A, Howe JR (2003) How AMPA receptor desensitization depends on subunit occupancy. J Neurosci 23:847-858.

Robert A, Irizarry SN, Hughes TE, Howe JR (2001) Subunit interactions and AMPA receptor desensitization. J Neurosci 21:5574-5586.

Ruiz A, Sachidhanandam S, Utvik JK, Coussen F, Mulle C (2005) Distinct subunits in heteromeric kainate receptors mediate ionotropic and metabotropic function at hippocampal mossy fiber synapses. J Neurosci 25:11710-11718.

Smith TC, Wang LY, Howe JR (1999) Distinct kainate receptor phenotypes in immature and mature mouse cerebellar granule cells. J Physiol 517:51-58.

Vignes M, Collingridge GL (1997) The synaptic activation of kainate receptors. Nature 388:179-182.

Zhang W, St-Gelais F, Grabner CP, Trinidad JC, Sumioka A, MorimotoTomita M, Kim KS, Straub C, Burlingame AL, Howe JR, Tomita S (2009) A transmembrane accessory subunit that modulates kainate-type glutamate receptors. Neuron 61:385-396. 